\title{
Re-description of eight species described by Luigi Balzan from South America (Argentina, Brazil, Paraguay) (Pseudoscorpiones: Chernetidae)*
}

\author{
V. MAHNERT \\ Volker Mahnert, Muséum d'histoire naturelle de la Ville de Genève, case postale 6434, CH-1211 \\ Genève 6, Switzerland.E-mail: volker.mahnert@wanadoo.fr
}

\begin{abstract}
Lectotypes are designated for Chelifer brevifemoratus, Chelifer communis, Chelifer crassimanus, Chelifer foliosus, Chelifer germainii, Chelifer robustus, Chelifer (Lamprochernes) cervus, Chelifer (Lamprochernes) ovatus; the species are redescribed and their generic placement is discussed. Gomphochernes depressimanus (With, 1908) and Gomphochernes perproximus Beier, 1932 are considered as subjective junior synonyms of G. robustus. Chelifer ovatus is transferred to the genus Americhernes Muchmore (nov. comb.). Chelifer brevifemoratus is removed from synonymy of Lamprochernes savignyi (E. Simon) and transferred to the genus Parachernes (nov. comb.).
\end{abstract}

Keywords. taxonomy, lectotypes, new combinations, new synonyms.

\section{INTRODUCTION}

$\mathrm{L}$ uigi Balzan was born in 1865 in Badia (Italy) and moved to Paraguay in 1886, obtaining there the chair of Professor of Natural History at the National Institute. He started exploring the country and collected intensively different animal groups and published, first in a private edition $(1887,1888)$, then in 1890 in Italy, the pseudoscorpion fauna of Paraguay, describing 27 new species. He died in 1893 at the age of only 28 years in Padua (Italy). Several of his species have subsequently been recorded from many parts of South and Central America. Balzan's pseudoscorpion collection was untraceable, and With (1908) redefined some of Balzan's species without having seen the original specimens. His detailed descriptions were taken over by Beier (1932b) for his monumental synopsis of the pseudoscorpions. One century later fortunately, I could trace, with the help of Italian colleagues, an important part of Balzan's collection in the Museo La Specola at Florence and thanks to the helpful collaboration of the responsible at this time, Dr Sarah Mascherini, I was finally able to study many species described by Balzan from Paraguay and adjacent regions. Several species have already been redescribed and lectotypes designated (Mahnert 1985, 2013, Mahnert \& Aguiar 1986), and I take the occasion here to precise the taxonomic position of eight Chernetid species for which a good definition was lacking and which had been therefore confused or partly misplaced. This might enable a new discussion on affinities between genera and species based on precise morphological data.

\section{MATERIAL AND METHODS}

Measurements are given in $\mathrm{mm}$; proportions and measurements of pedipalps and carapace correspond to length/breadth, those of legs to length/depth. Terminology follows mainly Chamberlin (1931) and Harvey (1992), measurements follow Beier (1932a). The species are arranged in alphabetic order of their name, in the synonyms'

urn: 1sid:zoobank.org:pub:4B24832F-560F-492D-A37E-9374F9BC4DC3

HU ISSN 2063-1588 (online), HU ISSN $0237-5419$ (print) http://dx.doi.org/10.18348/opzool.2016.1.73

*This paper is dedicated to Andras Zicsi, in memory of our common field and collecting trips. 
list are only mentioned the original name, the generic placement by Beier (1932b) and (if different) the current placement indicated by Harvey (2013) where complete synonymies are listed. Due to the bad conservation status of most specimens, drawings are concentrating on the most important characters, vestitural setae e.g. had been omitted on pedipalps and chela; furthermore, these details are well figured by Balzan $(1887,1888)$.

All specimens studied here are housed in the collections of the Museo Zoologico La Specola, Florence (Italy).

\section{TAXONOMY}

\section{Parachernes brevifemoratus (Balzan) comb. nov.}

(Figures 1-3)

Chelifer brevifemoratus (Balzan, 1887): no pagination, figs.

Pycnochernes brevifemoratus (Balzan): Beier 1932b: 137.

Material examined. Paraguay, Asuncion, sotto base foglie di Cocos (coll. no. 30); Lectotype $\widehat{\widehat{\sigma}}$ (designated here, designation label dates from 1983) (type series consisting of $1 \hat{0}, 2$ ㅇ 10 nymphal stades; badly conserved, broken, and partly incomplete). Paralectotypes; remaining specimens.

Balzan (1887) mentioned a total of 13 specimens (one from Resistencia, 12 from Asuncion). Balzan (1890) cited one specimen from Resistencia ("sotto la corteccia d'un tronco morto"), this specimen probably has been mixed up with those from Asuncion.

Description of lectotype. Carapace granular, the granula regular and separated by their diameter, surface between eye-spots smooth, tergites excepted XI divided, anterior ones granular, the last ones scaly sculptered; pedipalps coarsely granular, setae on carapace and tergites clavodentate, being longer on the posterior tergites; setae on pedipalps relatively long and clavodentate, on hand dentate. Carapace 1.2 times longer than broad, two indistinct eye-spots present, with two narrow transversal granular furrows, subbasal one indistinctly nearer to posterior margin than to median one; 4 setae on anterior, 10 setae on posterior margin; half-tergites I-III with 6-7 marginal setae, IV-X with about 5-6 setae on posterior margin, 1 lateral and 1 median anterior seta, XI 10 setae (4 median discal setae, tactile broken or absent). Manducatory process with 3 marginal and 1 discal setae; genital operculum with about 30 long and smooth setae, genital opening with $3 / 3$ acute internal setae; chaetotaxy of half-sternites III-XI: $5+3 / 5+2 / 8 / 9 / 7 / 5 / 5 / 3$, on VII-X biserial setation ( 1 or 2 lateral, median and discal setae), sternite XI 8 (2 median discal setae, 2 lateral tactile setae). Spermatheca of female (Fig. 3) paired, the short ducts with apical bulge.

Chelicera. 5 setae on hand, basal one finely dentate, movable finger with tooth-like subapical lobus, serrula exterior 17 blades, galea short, acute, with 1-2 tiny teeth, galea of female longer, with apical fork and 4 lateral branchlets, rallum 3 setae.

Pedipalps (Fig. 1). Trochanter with broad dorsal hump, 1.3 times longer than broad, femur abruptly enlarged, 2.0 (ㅇ 2.2 ) times, patella 2.2 ( + 2 2.0) times, hand with pedicel 1.6 (ㅇ 1.6) times, chela with pedicel 2.8 ( 9 2.7-2.8) times, without pedicel 2.6 times longer than broad, hand with pedicel 1.1 ( $q$ 1.2) longer than finger; both fingers $(\hat{\jmath}+)$ with 29-34 small partly cusped teeth, on fixed finger 6-9, on movable finger 6-7 antiaxial accessory teeth and 2/1 paraxial accessory teeth.

Trichobothria (Fig. 2). et in distal finger third, $i t / i s t / e s t$ grouped in middle of finger, eb/esb/ib/isb at finger base on fixed finger, st on movable finger halfway between $s b$ and $t$; a long venom duct present in movable finger, nodus ramosus at level of trichobothrium $t$.

Leg $I V$. Femur+patella 4.3 times, tibia 3.7 times, tarsus 4.8 times longer than deep, tibia 1.1 times longer than tarsus; tarsus with a tactile seta (broken) in the middle of tarsus (TS $=0.48$ ) arolia undivided, shorter than simple claws, subterminal seta strongly curved. 
Measurements of $\delta(2$ ). Body length 1.52; carapace $0.59 / 0.47$. Pedipalps: trochanter 0.25 / 0.19 , femur $0.37 / 0.18(0.40-0.42 / 0.18-0.19)$, patella $0.40 / 0.18(0.42-0.43 / 0.20-0.22)$, length of pedicel 0.11 , hand with pedicel $0.39 / 0.25(0.45$ $0.46 / 0.28-0.29)$, length of pedicel 0.06 , length of finger $0.37(0.38-0.39)$, of chela with pedicel 0.71 (0.78-0.79), without pedicel 0.65; leg IV: femur +patella $0.38 / 0.09$, tibia $0.27 / 0.07$, tarsus 0.25 / 0.05 .

Remarks. Harvey (1987) proposed the synonymy of Ch. brevifemoratus with Lamprochernes savignyi (E. Simon), but he had ignored the existence of the type specimens. The bad conservation of the type specimens does not allow a definitive generic placement of the species, but it is evident that it does not belong to Lamprochernetinae, but has to be placed in Chernetinae, and putatively into the genus Parachernes. Differences between the close genera Rhopalochernes and Parachernes should be re-discussed. The trichobothrial pattern (ist-it) in middle of finger or proximal of and near $i b-i s b$, the presence of a tactile seta on tarsus IV and particularly the paired spermatheca are the main arguments for this generic placement.

\section{Odontochernes cervus (Balzan)}

(Figures 4-7)

Chelifer cervus Balzan, 1888: no pagination, figs. Odontochernes cervus (Balzan): Beier 1932b.

Material examined. Lectotype $\widehat{\sigma}$. Brasil, Matto -grosso (coll.no.129) (designated here, designation label is dated 1983). Paralectotype $P$. Same data (both specimens in bad condition, many setae fallen off or broken).

Balzan (1888) clearly states "Possideo exemp. 2 ex provincia Matto-grosso", but not in 1890: "Ne posseggo un solo esemplare proveniente dalla provincia brasiliana del Matto-grosso".

Description of lectotype (paralectotype ). Carapace 1.2 times longer than broad, laterally finely and densely granular, median transverse furrow distinct, 2 eye-spots present, 4 setae on anterior, about 15 on posterior margin, setae thin and finely dentate; tergites I-III and XI undivided, the other ones divided, with about 8 marginal, 1-2 lateral and median anterior setae and 2 discal setae; manducatory process with 3 marginal and 2 discal setae; coxae and sternites, genital organs unstudied. Chelicera with 5 setae (broken in ${ }^{\Uparrow}$ ), two basal ones finely dentate in $O$; fixed finger with 8 retrorse teeth, movable finger with long cone-like subapical tooth and 3 small marginal teeth, galea broken in $\hat{\partial}$, long with at least 4 lateral (one near base) and 2-3 apical branchlets, serrula exterior 18 blades, rallum 3 setae (distal one detate).

Pedipalps (Figs. 4-5). All segments finely granular, trochanter with high and rounded dorsal hump, femur smoothly enlarged, 2.4 (2.1) times longer than broad, patella 1.9 (2.1) times, club with a distinct hump on median face (much less pronounced in 9 ), hand with pedicel 1.5 (1.7) times, chela with pedicel 2.4 (2.6) times, without pedicel 2.3 (-) times longer than broad, hand with pedicel 1.3 (1.4) times longer than finger; finger strongly gaping (less pronounced in ()), fixed finger with 43 small cusped teeth, 11 antiaxial and 9 paraxial accessory teeth, movable finger with 48 marginal teeth, 10 antiaxial and 10 paraxial accessory teeth, short venom canal present in movable finger, nodus ramosus proximal of trichobothrium $t$ in distal third of finger.

Trichobothria (Fig. 6). et near finger tip, it slightly proximal, ist-est at same level distal of finger middle, it distinctly nearer to finger tip than distance between $i s t-i s b$; st on movable finger slightly nearer to $s b$ than to $t$.

Leg IV. Femur+ patella 3.5 (3.1) times, tibia 5.1 (4.2) times, tarsus 5.4 (4.7) times longer than deep, tibia 1.5 (1.4) times longer than tarsus; tibia probably with a tactile seta in middle $(\mathrm{TS}=0.52$ $0.54)$, tarsus with a basal tactile seta ( $\mathrm{TS}=0.23$ ) (enlarged alveoles present); claws of legs I-IV with big ventral tooth (ðㅇ) (Fig. 7).

Measurements of lectotype (paralectotype + , when measured). Carapace 1.47/1.23. Pedipalps: femur $1.40 / 0.59$ (1.11/0.53), patella $1.48 / 0.78$ $(1.19 / 0.56)$, hand with pedicel $1.65 / 1.12(1.42 /$ 0.86 ), length of pedicel 0.16 , of finger 1.28 


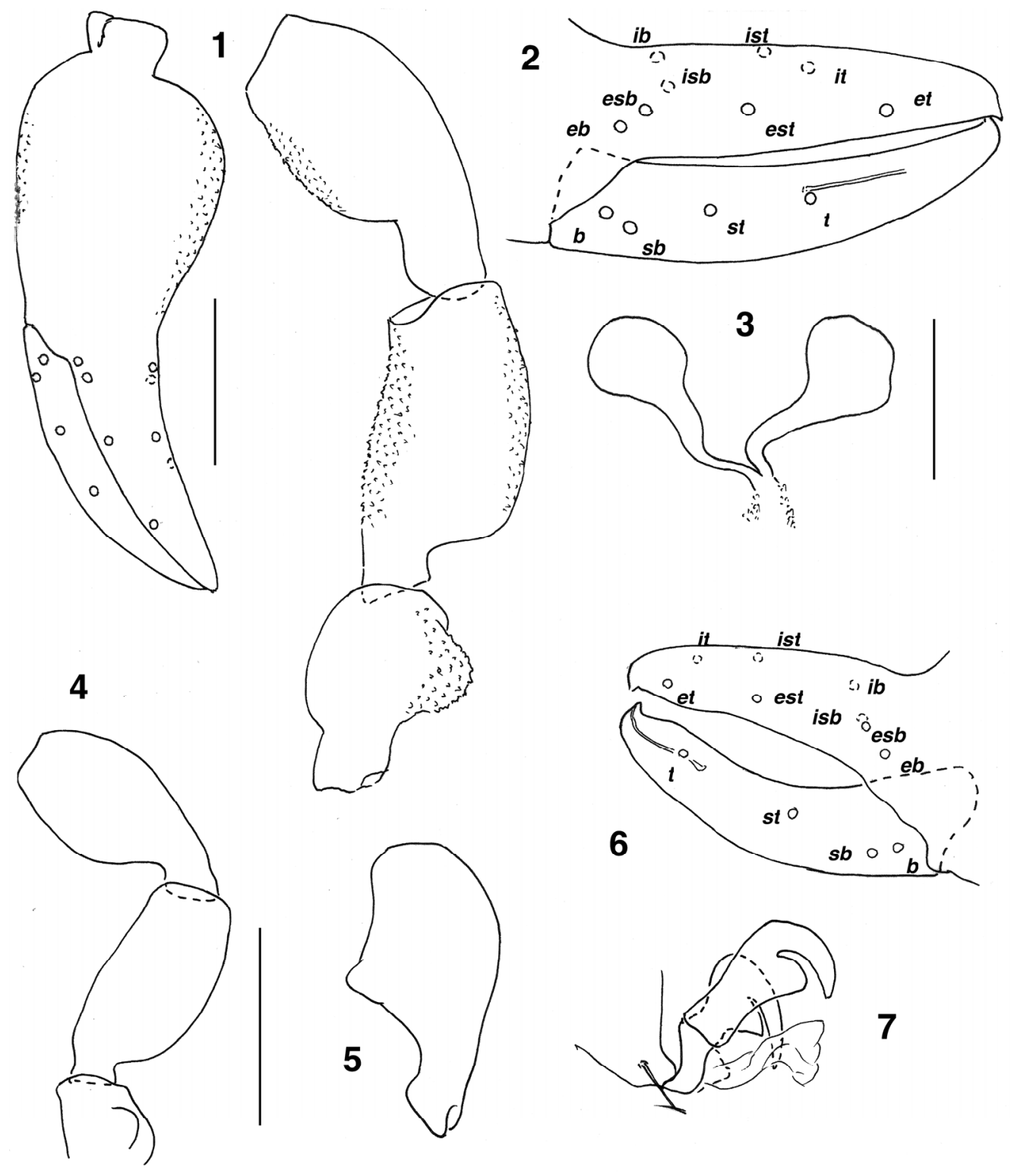

Figures 1-3. Parachernes brevifemoratus (Balzan), lectotype; 1 = pedipalp, 2 = trichobothrial pattern, $3=$ spermatheca; scale bar Fig. $1=0.2 \mathrm{~mm}$; Fig. $3=0.1 \mathrm{~mm}$.

Figures 4-7. Odontochernes cervus (Balzan), lectotype; $4=$ pedipalp $q$ (without chela), $5=$ patella $\widehat{\delta}$ (paralectotype), $6=$ trichobothrial pattern, $7=$ claws of tarsus IV; scale bar Figs. 4,5 =1.0 mm:

(1.01), of chela with pedicel 2.67 (2.28), without pedicel 2.51. Leg IV: femur+patella $1.42 / 0.41$ $(3.13 / 0.39)$, tibia $1.18 / 0.23(0.93 / 0.22)$, tarsus $0.77 / 0.14(0.65 / 0.14)$.

Remarks. Descriptions given by With (1908) and Beier (1932b) correspond well to the type specimen from Mato-Grosso, adding some indications on individual variation of several taxonomic characters (measurements, proportions). This monotypic genus is known from a few localities in Brazil (Mato-Grosso, Amazonas) and from Suriname. 


\section{Gomphochernes communis (Balzan)}

(Figures 8-11)

Chelifer communis Balzan, 1888: no pagination, figs. Lustrochernes communis (Balzan): Beier 1932b: 9091.

Gomphochernes communis (Balzan): Mahnert 1985. Gomphochernes depressimanus (With, 1908) syn. nov. Gompochernes perproximus Beier, 1932 syn. nov.

Material examined. Argentina, Chaco, Resistencia, sotto corteccie umide (coll. no. 33): q, lectotype (designated here, designation label dates from 1983). Paralectotypes, 5ㅅ, 3 으, same data. Paraguay, Rio Apa, sotto corteccie umide, paralectotypes, several specimens, not labelled "tipo", corresponding in morphological data to the series from Resistencia.

Balzan (1888) noted "Collegi exemp. 130 in colonia Resistencia, 13 in Asuncion, ac 69 in colonia Risso (in Apa fluminis territorio), in putrescente detrito sub arborum corticibus; possideo 4 ex. provincia Matto-grosso), and in 1890 "Raccolsi moltissime esemplari di questa specie assai commune in Resistencia, in Asuncion ed al Rio Apa, nel detrito putrefatto sotto corteccie dei tronchi morti": I did not see specimens from Asuncion.

Description of lectotype (paralectotypes). Carapace 1.2 times longer than broad; with 2 indistinct eye-spots, surface smooth, with a distinct median transverse furrow, posterior margin irregularly desclerotized, setae of carapace and tergites acute and thin, apically finely dentate, 4 on anterior, 11 (10) on posterior margin; tergites divided (excepted I,II,XI), half-tergites mostly with 6-8 marginal setae (I-III 6), on IV-IX with 1 lateral and 1 median anterior setae, IX-XI also with a median discal seta, XI (entire) 14 setae (2 lateral and 2 submedian tactile setae, 2 median discal setae). Manducatory process: 3 marginal and 2 discal setae, pedipalpal coxae smooth, about 21 setae, coxa I 12, II 13, III 14, IV numerous setae; genital operculum with $4 / 4$ median marginal setae and 14 setae in a central group, spermatheca (Fig. 10) paired, with egg-shaped distal part; sternites divided, III $4+3$ suprastigmal setae/ $4+1 / 8 / 8 / 8 / 7 / 8 / 7 /$, XI (entire) 16 setae, VI-X with 2-3 anteriorly set setae. Pleural membran striate.

Chelicera. Hand with 5 setae, three basal ones finely dentate, fixed finger with 4 retrorse teeth and 3 apical granula, movable finger with toothlike subapical lobe, galea long, with 6 (5-6) apical/subapical branchlets; rallum with 3 setae, the distal one anteriorly dentate, serrula exterior with 18 (17-18) blades.

Pedipalps (Fig. 8). Femur and patella finely and densely granular, chelal hand smooth; trochanter with pronounced and rounded dorsal hump, granular, 1.7 (1.6) times longer than broad, femur abruptly enlarged, 2.2 (2.1-2.2) times, patella $2.1(2.0-2.1)$ times, hand with pedicel 1.8 (1.8-1.9) times, chela with pedicel 2.8 (2.9-3.0) times, without pedicel $2.6(2.7-2.8)$ times longer than broad, hand with pedicel 1.6 (1.5) times longer than hand breadth and indistinctly gaping; fixed finger with 29 cusped teeth, 5 antiaxial and 3 paraxial accessory teeth, movable finger with 32 teeth, accessory teeth $6 / 2$; long venom duct present in movable finger, nodus ramosus proximal of trichobothrium $t$.

Trichobothria (Fig. 9). est in proximal third of fixed finger, ist-it in finger middle, et near finger tip; distance $i$-finger tip distinctly longer than distance between ist/isb; st on movable finger nearer to $s b$ than to $t$, which is situated distal of the finger middle.

Leg IV. Femur+patella 2.6 (2.4-2.6) times, tibia 3.6 (3.2-3.5) times, tarsus 3.8 (3.5-3.8) times longer than deep, tactile seta on tarsus in basal third ( $\mathrm{TS}=0.25)$; subterminal seta smooth, curved; arolia undivided, as long as claws; internal claw with distinct and broad tooth on inferior margin (Fig. 11).

Measurements of lectotype (paralectotypes $\hat{\sigma}$ + ). Body length - (2.2-2.6); carapace 0.81/0.68 (0.68-0.85/0.55-0.71). Pedipalps: trochanter 0.44/ $0.25(0.33-0.39 / 0.21-0.25)$, femur $0.69 / 0.32(0.51$ $-0.62 / 0.25-0.29)$, patella $0.70 / 0.34 \quad(0.53-0.63 /$ $0.26-0.31)$, length of pedicel $0.18(0.14-0.18)$, hand with pedicel $0.80 / 0.44(0.60-0.71 / 0.33-$ $0.38)$, length of pedicel $0.10(0.07-0.09)$, of finger $0.50(0.40-0.47)$, of chela with pedicel 1.21 
(0.95-1.10), without pedicel $1.12(0.89-1.01)$. Leg IV: femur+patella $0.66 / 0.26(0.51-0.62 / 0.20$ $0.25)$, tibia $0.50 / 0.14(0.38-0.48 / 0.12-0.14)$, tarsus $0.33 / 0.09(0.26-0.31 / 0.08)$.

Supplementary specimens. Specimens collected during the expedition 1979 of the Geneva Museum of Natural History to Paraguay correspond perfectly to the above given description of the lecto- and paralectotypes. They were collected in the following localities (leg. V. Mahnert): Paraguay, prov. Concepcion, Rio Apa, south of Estancia Estrellas, under bark, 18.X.1979; prov. Concepcion, Rio Apa, between Estancia Estrellas and Estancia Primavera, under bark of fallen tree trunks, 18.X.1979; prov. Amambay, $12 \mathrm{~km}$ south Bella Vista, sieving of litter and rotten wood, 23.X.1979; prov. Canendiyu, near mouth of Rio Carapa, sieving of dead leaves and rotten wood, 3.XI.1979.

Remarks. The species Chelifer communis Balzan has been transferred to the genus Gomphochernes by Mahnert (1985), but without giving detailed information on it and without official designation of a lectotype. The species Lustrochernes communis (Balzan) sensu Beier (1932b) had been identified as being identical with Lustrochernes intermedius (Balzan), with designation and description of a lectotype (Mahnert 1985).

The transfer of communis invites to the comparison with the two hitherto known species in Gomphochernes; depressimanus (With, 1908) and perproximus Beier, 1932 (type species of the genus). Based on the descriptions of those two species, both species can be considered identical with communis and therefore should be considered as junior subjective synonyms of communis. Specimens of perproximus (original description) show slightly smaller size in pedipalpal measurements, compared to communis, e.g. length of femur $\widehat{\delta} 0.47 \mathrm{~mm} / q 0.56 \mathrm{~mm} \mathrm{vs}$. $\hat{\sigma}$ $0.56-0.62 \mathrm{~mm} /$ क $0.51-0.59 \mathrm{~mm}$, of patella $\widehat{\delta}$ $0.48 /$ \& $0.56 \mathrm{~mm}$ vs ${ }^{\lambda} 0.55-0.63 /$ o $0.53-0.70$, length of chela with pedicel $\delta 0.89 \mathrm{~mm} / \phi 1.04$ $\mathrm{mm} v s$. ठ $1.00-1.08 \mathrm{~mm} /$ o $0.95-1.21 \mathrm{~mm}$.
These small differences seem to be not significant to maintain them as different species. The three species had still been differentiated by Mahnert et al. (2011), based on published descriptions and on the lectotype only, without taking in account variability of characters.

\section{Parachernes crassimanus (Balzan)}

(Figures 12-13)

Chelifer crassimanus Balzan, 1887: no pagination, figs.

Parachernes (Argentochernes) crassimanus (Balzan): Beier 1932b: 121-122.

Material examined. Argentina, Chaco, Resistencia, sotto corteccie secche (coll.45), lectotype, 1 ㅇ (designated here, designation label dates from 1983) (Balzan 1887: "Collegi sub truncorum corticis exemp. 1 in colonia Resistencia").

The specimens from Asuncion (Balzan 1890: sotto corteccie secche (coll.no.45): 1ठ 10T 1P) belong without doubt to another Parachernes species, probably P. plumosus (With).

Balzan (1887) noted "possideo exemp. 9 ex. provincia Matto-grosso", en affirmant (1890) "ne posseggo pure parecchi del Matto-grosso".

Description of the lectotype. Colouration not discernable, but pedipalpal hand apparently darker than other segments. Carapace and pedipalps coarsely granular, granula on carapace regular, separate by one diameter from each other, setae short, dentate and slightly clavate, those on hand dorsum finely dentate, but not clavate; tergites except XI divided, I-VI scaly, the others smooth, setae slender, longer on the posterior ones, dentate and slightly clavate. Carapace 1.1 times longer than broad, 2 indistinct eye-spots present, prozone between eyes smooth, 4 setae on anterior, 10 on posterior margin; chaetotaxy of half-tergites I-X: $6 / 5 / 6 / 7 / 6 / 6 / 4 / 5 / 5 / 5$, on III-X one lateral anterior seta, tergite XI 8 (2 median discal setae, tactile setae, ?broken). Manducatory process with 3 marginal and 1 discal setae; genital operculum 
with $3 / 4$ median marginal and about 25 central discal setae; spermatheca not observed; halfsternites III-X: $5+3$ suprastigmal setae/4+1/6/8/7/ $8 / 9 / 8$, entire sternite XI 8 setae (tactile setae, ?broken). Pleural membran granular.

Chelicera. 5 setae on hand, at least one basal one finely dentate, movable finger with tooth-like subapical lobe, galea long with 6 apical and subapical curved branchlets, serrula exterior 22 blades, rallum 3 setae, distal one dentate.

Pedipalps (Fig. 12). Trochanter with prominent rounded dorsal hump, 1.6 times longer than broad, femur abruptly enlarged, 2.4 times, patella 2.3 times, hand with pedicel 1.6 times, chela with pedicel 3.1 times, without pedicel 2.8 times longer than broad, finger as long as hand with pedicel, distinctly gaping (movable finger curved); fixed finger with 41, movable finger with 47 small teeth, accessory teeth $6 / 5$ on antiaxial side, $3 / 2$ on paraxial side; venom duct present in movable finger, nodus ramosus at level of trichobothrium $t$.

Trichobothria (Fig. 13). et in distal third of fixed finger, it-ist-est near finger base, quite close to $e b-e s b-i b-i s b$.

Leg III (IV lacking). Femur+patella 2.5 times, tibia 3.6 times, tarsus 4.0 times longer than deep, tarsus with a (broken) tactile seta in distal third (TS=0.70).

Measurements. Carapace 0.83/0.75. Pedipalps: trochanter $0.37 / 0.22$, femur $0.57 / 0.24$, patella $0.61 / 0.27$, length of pedicel 0.19 , hand with pedicel $0.57 / 0.35$, length of pedicel 0.11 , of finger 0.58 , of chela with pedicel 1.08 , without pedicel 0.98 ; leg III: femur+patella $0.49 / 0.20$, tibia $0.51 / 0.11$, tarsus $0.31 / 0.08$.

Remarks. Morphological details given by With (1908) and by Beier (1932b) are based on two 우 from Venezuela (La Moka) and do not correspond to those of the lectotype from Argentina (Resistencia) (Mahnert et al. 2011): bigger size (e.g. length of pedipalpal femur $0.80 \mathrm{~mm} v s .0 .57 \mathrm{~mm}$, of patella $0.83 \mathrm{~mm} v s .0 .61 \mathrm{~mm}$, of hand with pedicel $0.83 \mathrm{~mm} v s .0 .57 \mathrm{~mm}$; chelal fingers not gaping vs. distinctly gaping, a different trichobothrial pattern (est in distal finger half near et, itist in distal half of fixed finger vs it-ist grouped with est near base of fixed finger.
The status of the species described by With (1908) (and Beier 1932b) is uncertain (With, l.c.: "It is with greatest hesitation that I have referred...to Ch. crassimanus..") and cannot be clarified here. The differences between $P$. crassimanus as defined here and $P$. melanopygus Beier, 1959 are subtle (Mahnert et al. 2011), new specimens of crassimanus are necessary to settle a possible synonymy between both species.

\section{Pseudopilanus foliosus (Balzan)}

(Figures 14-17)

Chelifer foliosus Balzan, 1887: no pagination, figs.

Rhopalochernes foliosus (Balzan): Beier 1932b.

Pseudopilanus foliosus (Balzan): Beier 1977.

Material examined. Argentina, Chaco, Resistencia, sotto corteccie secche, "Tipo": $\widehat{\curlywedge}$ Lectotype (designated here, designation label dates from 1983) (bad condition; leg I, right chelicera missing, most setae broken off).

Balzan had two specimens, one from Resistencia, and one from Asuncion ("che è giovane") but this latter was not present in the collection studied.

Description. Carapace as long as broad, nearly pave-stone-like sculptured, prozone on lateral sides finely granular, surface nearly smooth, two distinct smooth transverse furrows, subbasal furrow nearly halfway between median furrow and posterior margin, two big lensed eyes present, setae (as those of tergites) strongly clavate, 4 on anterior, 11 on posterior margin. Tergites divided, except I and XI, scaly ctenoid sculptured, mostly 6-8 marginal setae, III-X also with a lateral and a median anterior seta, XI (entire) with 13 setae (no tactile setae, but 4 discal ones). Manducatory process with 3 marginal and 2 discal setae, coxae not examined; genital operculum with about 50 setae in semicircular arrangement; genital organ not examined; half-sternites with about 76-80 marginal setae, about 1 suprastigmal seta on each side, IX-X with one lateral anterior seta, XI not examined. Pleural membran granular (granula nearly star-like). 


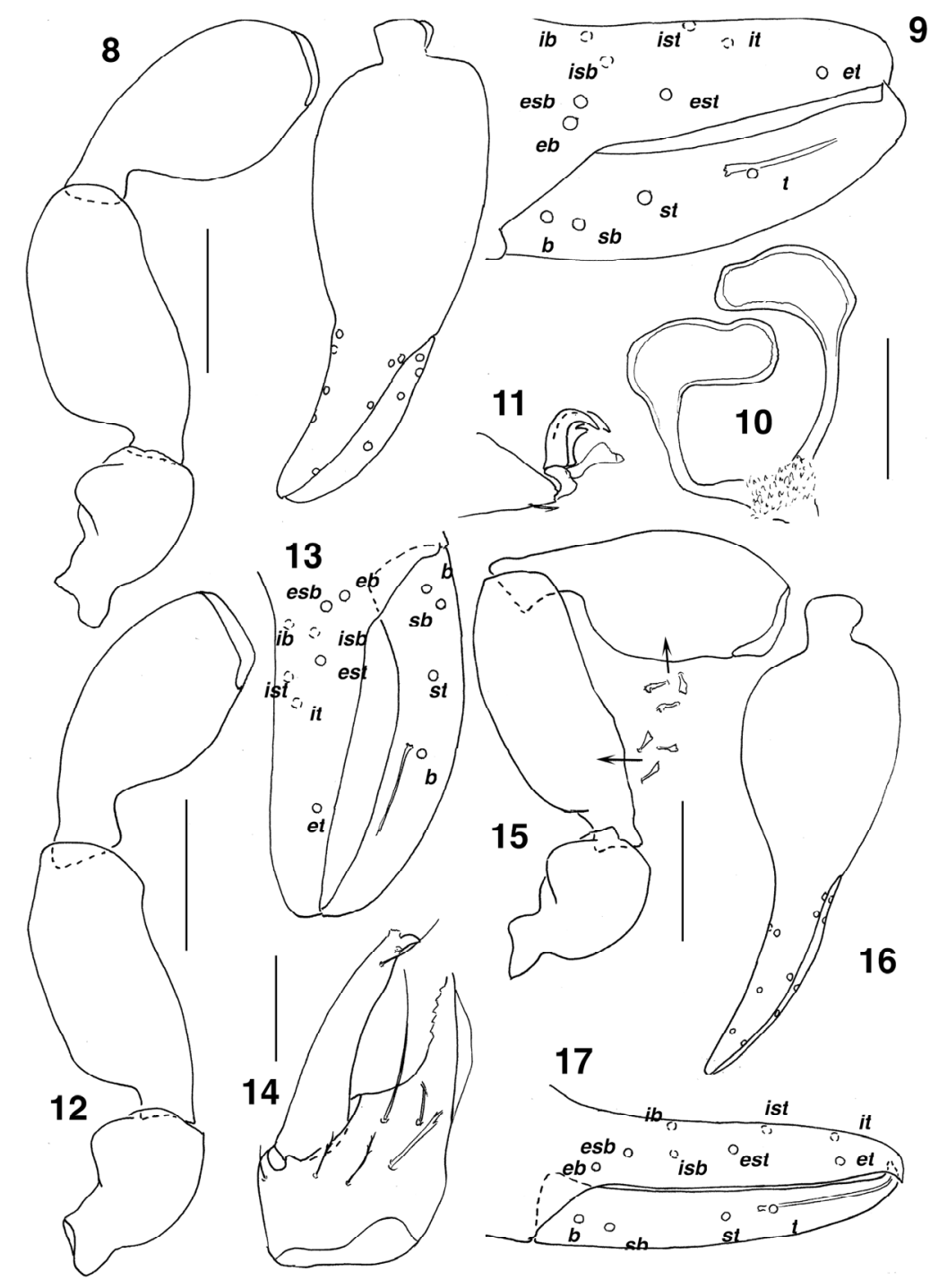

Figures 8-11. Gomphochernes communis (Balzan), lectotype; $8=$ pedipalp, $9=$ trichobothrial pattern, $10=$ spermatheca, $11=$ claws of tarsus IV; scale line Fig. $8=0.3 \mathrm{~mm}$, Fig. $10=0.1 \mathrm{~mm}$.

Figures 12-13. Parachernes crassimanus (Balzan), lectotype; 12 = pedipalp (without chela), 13 = trichobothrial pattern; scale line Fig. $12=0.3 \mathrm{~mm}$.

Figures 14-17. Pseudopilanus foliosus (Balzan), lectotype; $14=$ left chelicera, 15-16 = pedipalp and chela, $17=$ trichobothrial pattern; scale line Fig. $14=0.1 \mathrm{~mm}$, Figs. $15-16=0.4 \mathrm{~mm}$.

Chelicera (Fig. 14). With 6 setae, three basal ones dentate, fixed finger with 6 retrorse and 3 apical tiny teeth, movable finger with a small tooth-like subapical lobe, galea broken, serrula exterior 19 blades, rallum 3 setae.

Pedipalps (Figs. 15--16). Densely granular, setae clavodentate, trochanter with high rounded dorsal hump, 1.7 times longer than broad, femur abruptly enlarged, 2.8 times, patella 2.2 times, hand with pedicel 1.8 times, chela with pedicel 3.1, without pedicel 2.8 times longer than broad, hand with pedicel 1.15 times longer than finger; fixed finger with 38 marginal teeth, 6 antiaxial and 3 paraxial accessory teeth, movable finger with 44 marginal teeth, accessory teeth $3 / 3$, venom duct present in movable finger, nodus ramosus proximal of trichobothrium $t$.

Trichobothria (Fig. 17). et-it near finger tip, 
ist distal of est (both in finger middle), est distinctly nearer to ist than to isb, st on movable finger close to $t$.

Leg IV. Femur+patella 3.4 times, tibia 3.6 times, tarsus 5.3 times longer than deep, tarsal tactile setae apparently absent, claws smooth, subterminal seta curved and smooth.

Measurements. Carapace 1.04/1.03. Pedipalps: trochanter $0.57 / 0.34$, femur $0.92 / 0.33$, patella $0.93 / 0.42$, length of pedicel 0.30 , hand with pedicel $0.88 / 0.50$, length of pedicel 0.16 , of finger 0.77 , of chela with pedicel 1.58 , without pedicel 1.42. Leg IV: femur+patella $0.83 / 0.24$, tibia $0.68 /$ 0.19 , tarsus $0.55 / 0.10$.

Remarks. The species foliosus had been placed for long years in the genus Rhopalochernes, but in 1977 Beier transferred it to the genus Pseudopilanus Beier, 1957, without argumentation. Pseudopilanus (type species fernandezianus Beier from the Juan-Fernandez-Islands) is characterized mainly by the following characters: rallum with 3 setae, vestitural setae strongly clavate, hand with paraxial spine-like setae, chelal fingers without accessory teeth, trichobothria et-it near finger tip and nearly at same level, tarsus of leg IV without tactile seta. Eight species are currently placed in this genus, some without spine-like setae on pedipalps, some with accessory teeth on chelal fingers, but all sharing the absence of a tactile seta on tarsus IV and the distal position of trichobothrium it at level of et (as emphasized by Beier 1964).

Feio (1945) decribed Neochernes melloleitao from Argentina (Santiago del Estero) and according to the main taxonomic characters it represents probably a synonym of foliosus, but its type specimens have not been checked.

\section{Rhopalochernes germainii (Balzan)}

(Figures 18-20)

Chelifer germainii Balzan, 1887: no pagination, figs. Rhopalochernes germaini (Balzan): Beier 1932b.

Material examined. Lectotype ô, Brasil, Matto -grosso (coll. no. 46) (designated here, desig- nation label dates from 1983). Paralectotypes, $1{ }^{\widehat{ }}$ 1 , , same data (all specimens in bad condition, partly in fragments).

Description. Carapace finely granular, granula separated by one diameter, median prozone smooth, setae of carapace and tergites clavoclavate, setae of pedipalps short, on femur and patella clavodentate (the lateral ones finer), on hand merely clavate, those on fingers acute. Carapace with 2 indistinct eye-spots, two narrow transverse furrows present, the median one curved laterally cephad, the subbasal one nearer to posterior margin than to median furrow, both granular at bottom, 4 setae on anterior, 8 on posterior margin; tergites (except I, XI) divided, with mainly 5-7 marginal setae, one lateral and one median anterior seta on IV-X, XI (entire) with 12 setae (4 discal setae). Manducatory process with 3 marginal setae, one discal seta present(?); chaetotaxy of coxae unstudied; genital operculum with about 50 long and acute setae (arranged in several rows); male genital organ not studied, spermatheca paired (Fig. 20); half-sternites with about 68 marginal acute and thin setae, on $\mathrm{X}$ one lateral seta clavodentate. Pleural membrane striate.

Chelicera with 5 acute long setae on hand (chelicerae missing in lectotype and $O$ paralectotype), movable finger with a small tooth-like subapical lobe, serrula exterior 17 blades, rallum 3 setae, the distal one serrate.

Pedipalps (Fig. 18). Distinctly granular, trochanter with a distinct rounded dorsal hump, femur basally gently enlarged, 3.3 times, patella 2.6 times, hand with pedicel 2.0 times longer than broad, finger 1.2 times, chela with pedicel 3.3 times, without pedicel 3.1 times longer than broad; both chelal fingers with 40 cusped marginal teeth, 4 (3) antiaxial and 2 (2) paraxial accessory teeth; venom duct present in movable finger, nodus ramosus proximal of trichobothrium $t$.

Trichobothria (Fig. 19). et in distal finger half, it distinctly distal of ist, est halfway between ist and $i s b$ in proximal third of finger; $s t$ on movable finger nearer to $s b$ than to $t$.

Leg IV. Femur+patella 3.0 times, tibia 4.4 times, tarsus 4.6 times longer than deep, tarsus without (?) tactile seta, claws simple, arolia undivided, subterminal seta smooth, curved. 
Measurements of lectotype. Carapace 0.66/ 0.60 . Pedipalps: trochanter $0.32 / 0.18$, femur $0.55 /$ 0.17 , patella $0.51 / 0.20$, length of pedicel 0.14 , hand with pedicel $0.54 / 0.28$, length of pedicel 0.06 , of finger 0.44 , of chela with pedicel 0.92 , without pedicel 0.87 . Leg IV: femur+patella $0.50 /$ 0.17 , tibia $0.37 / 0.08$, tarsus $0.28 / 0.06$.

Remarks. The description given by Beier (1932b) is quite concordant with that of the type specimens studied. To complete iconographie of this species, figures of pedipalps and spermatheca are given.

Americhernes ovatus (Balzan, 1892) comb. nov.

(Figure 21)

Chelifer (Lamprochernes) ovatus Balzan, 1892: 519, fig. 10, 10a.

Lustrochernes ovatus (Balzan): Beier 1932b.

Material examined. Holotype $\odot$, Brazil, Caraça, Minas (coll. no. 130) "Tipo" (Balzan had one specimen at disposition:.. in unico exemplo..).

Description. Carapace 1.2 times longer than broad, smooth, basally lightened, with a flat median transverse furrow, 2 big but not well marked eye-spots, with 4 setae on anterior and 8 on posterior margin, setae of carapace and tergites long, thin and finely dentate near apex, setae of pedipalps finely dentate; tergites except XI divided, half-tergites I-III with 3-5 marginal setae, IV-X with $6-8$ on posterior margin and one lateral and median anterior setae, XI (entire) with 16 setae (4 tactile setae?). Manducatory process with 3 marginal and 1-2 discal setae, pedipalpal coxa smooth, 21 setae, coxa I 13, II 14, III 14, IV numerous. Genital operculum with a median oval group of 12 setae and 7 marginal setae, spermatheca not observed; sternites divided, chaetotaxy of half-sternites: $5+2$ suprastigmal setae $/ 3+$ ? 7/7-9/7-8/6-8/8-9/6-7; V-X with 1-2 additional anterior setae on lateral and median margin; entire sternite XI 16 seta (2 lateral tactile, 2 median discal tactile setae). Pleural membran striate.

Chelicera. 5 long setae, 3 basal ones finely dentate, galea broken (right chelicera lacking), rallum probably with 3 setae, distal one dentate, serrula exterior with 21 blades.

Pedipalps. Trochanter finely granular, femur indistinctly and finely granular medially, patella and hand smooth, trochanter with prominent rounded dorsal hump, 1.7 times longer than broad, femur abruptly enlarged, lateral face strongly rounded, 2.0 times, hand with pedicel 1.8 times, chela with pedicel 2.8 times, without pedicel 2.7 times longer than broad, hand with pedicel 1.6 times longer than finger; finger not gaping; fixed finger with 40 small, uniform and cusped teeth, 11 antiaxial, 3 paraxial accessory teeth, movable finger with about 41 mostly cusped teeth, 9 antiaxial and 3 paraxial accessory teeth, venom duct present in movable finger, nodus ramosus slightly proximal of $t$.

Trichobothria (Fig. 21). it halfway between et and est, est-ist on same level in proximal finger half, distance between finger tip and it longer than distance between ist and $i s b$; st of movable finger nearer to $s b$ than to $t$.

Remarks. The trichobothrial pattern of the species corresponds to the definition of Americhernes Muchmore, 1976 (distance between finger tip and trichobothrium it distinctly longer than distance between ist and isb). This character (and the generic placement) should be verified on more specimens.

\section{Pachychernes robustus (Balzan)}

(Figures 22-23)

Chelifer robustus Balzan, 1888: no pagination, figs. Pachychernes robustus (Balzan): Beier 1932b.

Material examined. Brasil, Mato-Grosso, coll. no. 35: Lectotype $q$ (designated here, designation label dates from 1983). Paralectotypes, 2 , , same data (all in bad condition, many fragments).

Description of lectotype (paralectotypes). Carapace fine and densely granular, indistinctly longer than broad, median transverse furrow present, 2 eye-spots, 4 setae on anterior, 11 setae on posterior margin; tergites divided excepted XI, mostly with 5-7 marginal setae, one lateral and 


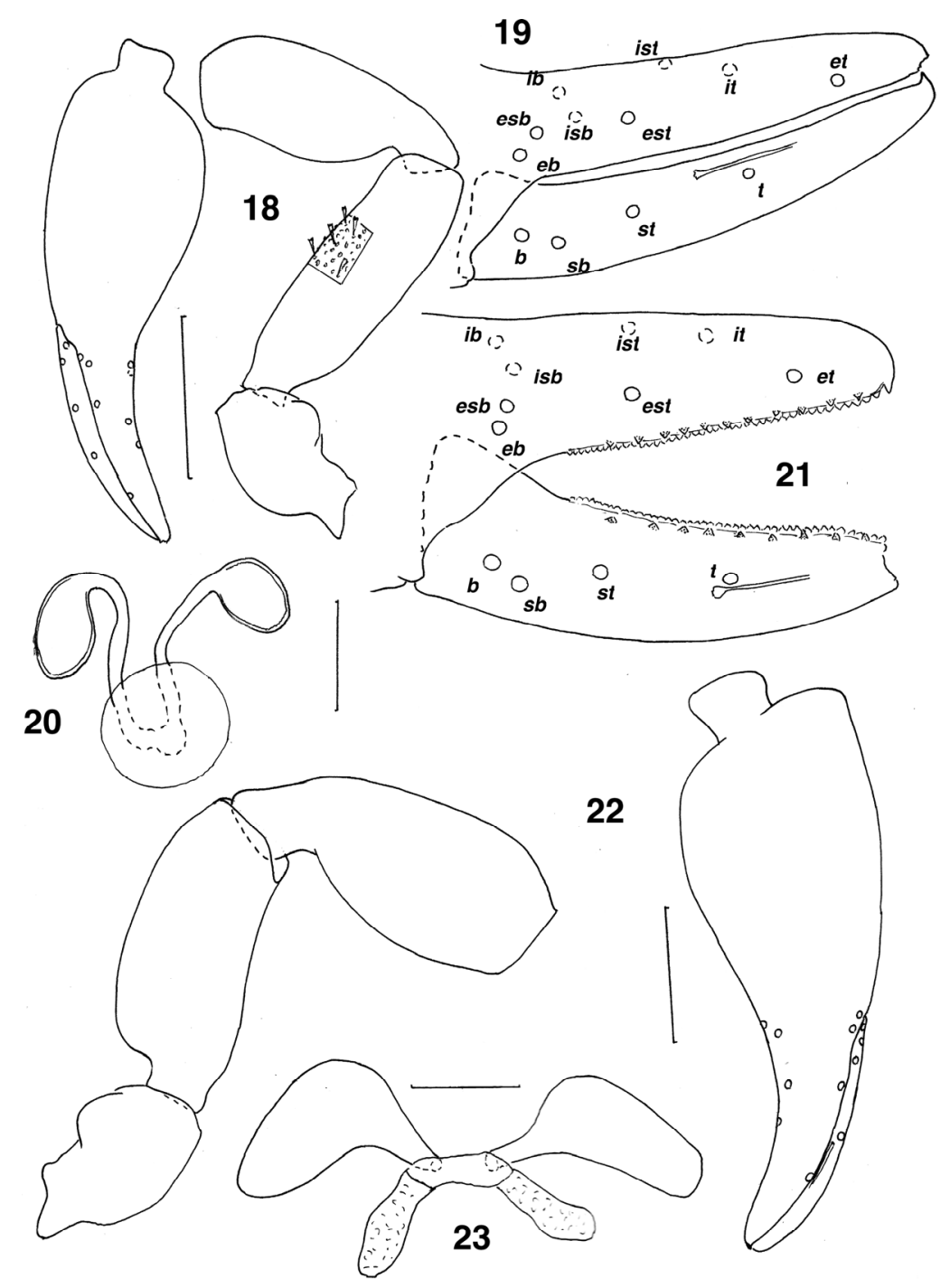

Figures 18-20. Rhopalochernes germainii (Balzan), lectotype; $18=$ pedipalp, $19=$ trichobothrial pattern, $20=$ spermatheca; scale line Fig. $18=0.3 \mathrm{~mm}$, Fig. $20=0.1 \mathrm{~mm}$.

Figure 21. Americhernes ovatus (Balzan), lectotype; trichobothrial pattern.

Figures 22-23. Pachychernes robustus (Balzan), lectotype; 22 = pedipalp, 23 = spermatheca; scale line Fig. $22=0.5 \mathrm{~mm}$, Fig. $23=0.1 \mathrm{~mm}$.

one median anterior seta, XI (entire) 12 setae (2 median discal setae); manducatory process with 3 marginal and 2 discal setae, pedipalpal coxa smooth, about 25 setae (long and acute), coxa I 16, II 12, III 23, IV numerous; genital operculum with about 40 setae; spermatheca paired (Fig. 23), sternites divided, mostly with 7 marginal setae, one lateral and one median anterior seta.
Chelicera. With 5 setae on hand, two basal ones dentate, $v t$ long and smooth; subapical lobe on movable finger small, tooth-like, galea broken, serrula exterior 26-27 blades, rallum 3 setae, the distal one serrate.

Pedipalps (Fig. 22). All segments finely granular on median side, trochanter with large dorsal hump, 1.7 times longer than broad, femur 
abruptly enlarged, 2.4 (2.4-2.6) times, patella 2.3 (2.2-2.4) times, hand with pedicel 1.85 (1.8) times, chela with pedicel 2.9 (2.8-3.0) times, without pedicel 2.7 times longer than broad, hand with pedicel 1.45 times longer than finger; fixed finger with 64 small cusped teeth, 10 antiaxial and 2 paraxial accessory teeth, movable finger with 69 marginal, 11 antiaxial and 0 paraxial accessory teeth; venom duct present in movable finger, nodus ramosus slightly distal of trichobothrium $t$.

Trichobothria. et on fixed finger halfway between finger tip and it, ist-est on same level distinctly proximal it and indistinctly nearer to it than to $i b / i s b ; s t$ on movable finger close to $s b, t$ isolated in distal finger half.

Leg IV. Femur+patella 2.5 times, tibia 4.3 times, tarsus 4.3 times longer than deep, tibia 1.48 times longer than tarsus; tarsus with tactile seta in basal third $(\mathrm{TS}=0.26)$, claws simple and smooth, arolium shorter than claws.

Measurements of lectotype (paralectotypes, when measured). Carapace 1.33/1.31. Pedipalps: trochanter $0.71 / 0.43$, femur $1.10 / 0.46$ (1.04$1.07 / 0.42-0.44)$, patella $1.27 / 0.54(1.18-1.20 /$ $0.50-0.55)$, length of pedicel 0.34 , hand with pedicel 1.37/0.74 (1.28-1.29/0.70-0.73), length of pedicel $0.16(0.11)$, of finger $0.94(0.91-0.94)$, of chela with pedicel 2.13 (2.02-2.07), without pedicel 2.00; leg IV: femur+patella 1.22/0.48, tibia 0.91/0.21, tarsus 0.61/0.14.

Remarks. The species has been characterized in a satisfactory way by Beier (1932b), the description of the type specimens brings up some more indications on variability of taxonomic characters and enables figures of exact trichobothrial pattern and spermatheca.

\section{REFERENCES}

BALZAN, L. (1887): Chernetidae Nonnullae Sud-Americanae, II. Asuncion (no pagination).

BAlZAN, L. (1888): Chernetidae Nonnullae Sud-Americanae, III. Asuncion (no pagination).

BALZAN, L. (1890): Revisione dei Pseudoscorpioni del bacino dei fiumi Parana e Paraguay nell'America meridionale. Annali di Museo civico di Storia naturale Giacomo Doria, serie 2, 9: 401-454, pl. XVII-XVII.

BALZAN, L. (1892): Voyage de M. E. Simon au Venezuela (Décembre 1887-Avril 1888). Arachnides, Chernetes (Pseudoscorpiones). Annales de la Société entomologique de France, 60: 497-454.

BEIER, M. (1932a): Pseudoscorpionidea I. Subord. Chthoniinea et Neobisiinea. Tierreich, 57: i-xx, 1258.

BEIER, M. (1932b): Pseudoscorpionidea II. Subord. C. Cheliferinea. Tierreich, 58: i-xiv, 1-294.

BEIER, M. (1957): Los Insectos de las Islas Juan Fernandez. 37. Die Pseudoscorpioniden-Fauna der Juan-Fernandez-Inseln (Arachnida Pseudoscorpionida). Revista Chilena de Entomologia, 5: 451-464.

BEIER, M. (1964): Die Pseudoscorpioniden-Fauna Chiles. Annalen des Naturhistorischen Museum Wien, 67: 307-375.

BeIER, M. (1977): XX. Pseudoscorpionidea. Mission zoologique belge aux Îles Galapagos et en Ecuador (N. et J. Leleup, 1964-1965), III: 93-112.

FEIO, J.L.A. (1945): Novos Pseudoscorpioes da regiao neotropical (com descriçao de uma subfamilia, dois generos e sete espécies). Boletim do Museo Nacional Rio de Janeiro, nova série, Zoologia, 44: $1-47$.

HARVEY, M.S. (1987): Redescriptions and new synonyms of the cosmopolitan species Lamprochernes savignyi (Simon) (Chernetidae: Pseudoscorpionida). Bulletin of the British arachnological Society, 7: 111-116.

HARVEY, M.S. (2013): Pseudoscorpions of the World, version 3.0. Western Australian Museum, Perth. http://www.museum.wa.gov.au/catalogues/pseudos corpions (accessed IX. 2015)

MAHNERT, V. (1980): In the tracks of Balzan in Paraguay. British arachnological Society, Secretary's News Letter, 27: 11-12.

MAHNERT, V. (1985): Pseudoscorpions (Arachnida) from the Lower Amazon region. Revista brasileira de Entomologia, 29(1): 75-80.

MAHNERT, V. (2013): The identities of two pseudoscorpion species (Arachnida) described from Guyana by L. di Caporiacco. Arachnology, 16(1): 16-20. doi: $\underline{10.13156 / \text { arac.2013.16.1.16 }}$ 
MAHNERT, V. \& AgUiAR, N.O. (1986). Wiederbeschreibung von Neocheiridium corticum (Balzan, 1890) und Beschreibung von zwei neuen Arten der Gattung aus Südamerika (Pseudoscorpiones, Cheiridiidae). Bulletin de la Société entomologique suisse, 59: 499-509.

MAhnert, V., Di IORIO, O., Turienzo, P. \& PortA, A. (2011): Pseudoscorpions (Arachnida) from Argen tina. New records of distributions and habitats, corrections and an identification key. Zootaxa, 2881: 1-30.

WITH, C.J. (1908): An Account of the South-American Cheliferinae in the Collections of the British and Copenhagen Museum. Transactions of the Zoological Society of London, 18: 217-340. doi: $\underline{10.1111 / \text { j.1469-7998.1907.tb07826.x }}$ 